\title{
Variations of Land Surface Temperature and Its Relationship with Land Cover and Changes in IPB Campus, Dramaga Bogor 2013-2018
}

\author{
Nafiriair Yufan Madakarah ${ }^{1, *}$, Supriatna ${ }^{2}$, Adi Wibowo ${ }^{2}$, Masita Dwi Mandini Manessa ${ }^{2}$, and Yoanna Ristya ${ }^{2}$ \\ ${ }^{1}$ Bachelor Program of The Department of Geography, Faculty of Mathematics and Natural Sciences, University of Indonesia, \\ 16424 Depok, Indonesia \\ ${ }^{2}$ Department of Geography, Faculty of Mathematics and Natural Sciences, University of Indonesia, 16424 Depok, Indonesia
}

\begin{abstract}
At the present time university can be called "small cities" due to their size of area, population and various kinds of activities. Bogor Agricultural University is a campus that can represent a city in smaller scope with a high variety of land cover. Further, the variation of land cover will affect the surface temperature variation. This study aims to determine spatial pattern of land surface temperature variation and relationship with land cover and also the changes. The data used in this study generated from Landsat 8 imagery and field surveys, then analyze using spatial and statistical analysis tools. The results show temperature has a spatial pattern associated with the land cover. Where the highest temperature tends to be located in the central region in the form of a built-up area and the lowest temperature tends to be located in northern region in the form of forest area. The highest increase in temperature tends to appear in the area that shows changes from vegetation to built-up area. Moreover, this study also found that this phenomenon only appears with temperature value were $7^{\circ} \mathrm{C}$ greater than the increase in temperature on a similar land cover. Finally, this study proves that the higher vegetation density will create a lower temperature of land surface, while the higher building density creates a higher land surface temperature.
\end{abstract}

Keywords: Land Surface Temperature; Land Cover; NDVI; NDBI.

\section{Introduction}

Urban development today is growing very rapidly, this is because they need for building increase and at the same time lead to changes in land cover (land cover change) [1]. These activities will result in less green open spaces that exist in the region, particularly in urban areas [2]. These developments lead to changes in climate elements, especially in the city center will be different from the surrounding area so that form phenomenon is known as the urban heat island (UHI). It is known that the Urban Heat Island phenomenon explains the occurrence of an increase in air temperature in urban areas that will reduce comfort [3].

The rapid development of the city makes changes on the earth's surface, where vegetated land decreases. The function of vegetated land to freshen the city air is reduced, causing the change in temperature. Temperature is the characteristics possessed by an object associated with the heat and energy [4]. The air temperature is an important thing in explaining the existing terrestrial environmental conditions on earth [5]. Based on numerous studies, there is a high correlation between air temperature and land surface temperature (LST), and it's based on the statistical approach [6].
Land use and land cover change (LULC) are considered as the most important variables of global changes that affect the ecosystem with a great impact on the environment related to climate change [7]. Changes in vegetation cover ordinary replaced by the surface that receives more solar heat and reflects it as the building and the road network in the form of asphalt or concrete. That situation will affect the redistribution of solar radiation, and trigger the contrast radiance and surface air temperature between rural and urban areas [8]. This phenomenon generally occurs in urban areas identified where the building or buildings, roads, parking areas and the surface of the non-vegetation [9]. Land cover changes not only in big cities but also occur in a university. University is an educational complex in the area of land cover is considered as the city on a smaller scale or small town [10].

Universities can currently be referred to as "Small Cities" refers to the size of the area, population and all sorts of activities that are within the campus which directly or indirectly have an effect on the environment [11]. As an area of education, universities have a variety of activities that may have an impact on the existence of land cover. Variations of these activities can dynamically change the shape of land cover in the campus area, which directly can impact on the variation of Land

\footnotetext{
* Corresponding author: nafiriair.yufan@ui.ac.id
} 
Surface Temperature (SPT) [12]. Land Surface Temperature (LST) can provide important information about the physical properties of surfaces. Land Surface Temperature plays an important role in the processes associated with changes in the surface temperature of the surrounding environment [13]. Based on the study, [14] describes the land surface temperature was analyzed further by investigating the relationship between the land surface temperature (LST), land cover, and two index Normalized Difference Vegetation Index (NDVI), Normalized Difference Building Index (NDBI).

Bogor Agricultural University seeks to realize the ideals of being a green campus that is eco-friendly by making program IPB toward Green Campus 2020. To realize itself as a Green Campus, Green Open Space (RTH) to be the focus of IPB as one of the variations in land cover. RTH is one of the indicators in the criteria Setting and Infrastructure where this indicator also indicates whether the campus is worth mentioning as Green Campus [15]. But as time went on, IPB did a lot of development which caused changes in land cover. When viewed from variations in existing land cover, IPB is considered to be able to represent a city in a smaller scope because it has the same diversity of land cover types as a city. The diversity of land cover is not owned by other campuses, therefore IPB is very suitable to represent a city that experiences the UHI phenomenon due to variations in land cover and changes in land cover. So, this study aims to determine the spatial pattern of variations in land surface temperature and its relationship with land cover and changes.

\section{Methodology}

\subsection{Study area}

IPB Campus is included in the Bogor Regency area, Dramaga District. IPB campus is geographically stretched between $06^{\circ} 32^{\prime} 411^{\prime \prime}-06^{\circ} 33^{\prime} 58^{\prime \prime} \mathrm{S}$ and $106^{\circ}$ $42^{\prime} 47^{\prime \prime}-106^{\circ} 44^{\prime} 07^{\prime} \mathrm{E}$ which is included in the Benteng Village next to the North, Babakan Village in the other side of the East and most of it is located in Cibanteng village. The area of Dramaga Bogor IPB campus is around $\pm 250 \mathrm{Ha}$ (Figure 1).

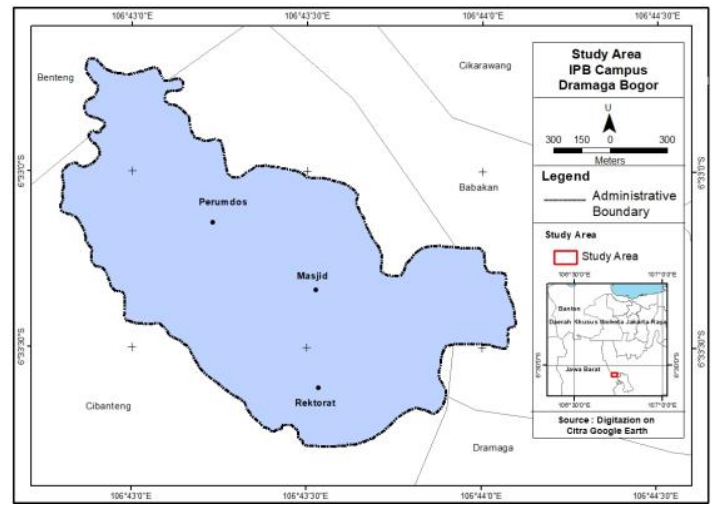

Fig. 1. Study Area IPB Campus Dramaga Bogor

\subsection{Data and Variable}

The variables used in this study included the form of land surface temperature (LST), land cover, vegetation density (Normalized Difference Vegetation Index) and built-up density (Normalized Difference Built-up Index). The variables used in this study were dependent and independent variables. The dependent variable is a variable that is affected by the independent variable, dependent variable magnitude depends on the magnitude of the independent variables. Table 1 shows the variables used in this study.

Table 1. Data and Variable

\begin{tabular}{|c|c|c|c|}
\hline No & Variable & Type of Variable & Information \\
\hline 1 & $\begin{array}{l}\text { Land Surface } \\
\text { Temperature }\end{array}$ & Dependent & $\begin{array}{c}\text { This variable is obtained from the } \\
\text { processing of Landsat } 8 \text { images from } \\
\text { band } 10 \text { (Thermal Infrared) and field } \\
\text { surveys }\end{array}$ \\
\hline 2 & Land Cover & Independent & $\begin{array}{l}\text { The land cover in question is like cement } \\
\text { / road network, buildings, grass, trees / } \\
\text { plants, and water bodies. This land cover } \\
\text { data is obtained from the results of } \\
\text { Google Earth processing and Digitization }\end{array}$ \\
\hline 3 & $\begin{array}{l}\text { Vegetation Density } \\
\text { (NDVI) }\end{array}$ & Independent & $\begin{array}{l}\text { NDVI is the result of a mathematical } \\
\text { approach that is based on reflecting } \\
\text { vegetation canopy which can be a ratio } \\
\text { value obtained from processing Landsat } \\
8 \text { images from the band } 5 \text { and band } 4\end{array}$ \\
\hline 4 & Built-up Density (NDBI) & Independent & $\begin{array}{l}\text { NDBI is an index that is sensitive to } \\
\text { constructed land / open land. NDBI was } \\
\text { created with the aim of facilitating the } \\
\text { mapping of urban areas through Landsat } \\
\text { satellites obtained from the processing of } \\
\text { Landsat } 8 \text { images from bands } 6 \text { and } \\
\text { band } 5\end{array}$ \\
\hline
\end{tabular}

\subsection{Data Processing}

In the first data processing process, the processing of Landsat 8 and Google Earth image data was processed. In the initial process of processing Landsat 8 images, the correction of the image is generally carried out which is generally geometric and radiometric correction while the processing of Google Earth data was digitized at the administrative boundary of the research area based on literature studies. For process, Landsat 8 imagery has L1T processing level (level-one terrain corrected) or has been free from errors due to sensors. So that data processing does not require geometric correction.

\subsubsection{Land Surface Temperature Processing}

The surface temperature obtained from the calculation of satellite brightness value. In this method, it is assumed that the water content in the atmosphere is constant for a small area, so it can be considered uniform atmospheric conditions and the influence of atmospheric conditions at temperatures radiance can be ignored.

In identifying the value of the land surface temperature wavelength used a thermal wave. On Landsat 8 OLI / TIRS, the band 10 used in processing the land surface temperature. In the processing of temperature data using Landsat 8 OLI / TIRS, steps that must be passed is to 
convert the pixel values of the image (DN) into spectral radiant.

$$
\begin{aligned}
& L \lambda=((L M A X \lambda-L M I N \lambda) /(Q C A L M A X-Q C A L M I N))) * \\
& (Q C A L-Q C A L M I N)+\text { LMIN }
\end{aligned}
$$

where :

$$
\mathrm{L} \lambda=\text { Spectral radiance }(\mathrm{wm}-2 \mathrm{SR}-1 \mu \mathrm{m}-1)
$$

$\mathrm{QCAL}=$ Digital number $(\mathrm{DN})$

LMIN $\lambda=$ Minimum value of the spectral radiance at the thermal band (wm-2sr- 1m-1)

LMAX $\lambda=$ Maximum value of spectral radiance at the thermal band (wm-2sr- $1 \mathrm{~m} \mathrm{1)}$

QCALMIN = Minimum quantized pixel value (typically $\mathrm{DN}=1$ ) corresponding to LMIN

QCALMAX=Maximum quantized pixel value (Typycally $\mathrm{DN}=255$ ) corresponding to LMAX

After obtaining a spectral radiation value is converted to estimate land surface temperature value by the formula:

$$
T=K 2 / \ln ((K 1 / L \lambda)+1
$$

where :

$\mathrm{T}=$ Temperature Obtained from satellite sensors (Kelvin)

$\mathrm{K} 1=$ Calibration constant 1 for Landsat OLI (774 $853 \mathrm{~K})$

$\mathrm{K} 2$ = Calibration constant 2 for Landsat OLI (1321.0789 K)

$\mathrm{L} \lambda=$ spectral radiance from the 10th band

After receiving the original Kelvin temperature value is converted into celcius, here the form of the algorithm:

$$
\text { LST (Celcius) }=T-272,15
$$

Temp-Kelvin is the estimation of land surface temperature from a satellite sensor in Kelvin. TempCelsius is the International Standard for land surface temperature in degrees Celsius, where one Kelvin is equivalent to $272.15{ }^{\circ} \mathrm{C}$. The value of land surface temperature in degree Celsius related to land-use/landcover types, and the heat emitted from their surface [16].

\subsubsection{Derivation of Normalized Difference Vegetation Index (NDVI)}

Vegetation density (NDVI) value obtained from the processing of NDVI in the following formula [17].

$$
N D V I=(N I R-R E D) /(N I R+R E D)
$$

where :

NDVI = Normalized difference vegetation index or indices of vegetation conditions.

NIR $=$ Near-infrared reflectance or near-infrared light, Band 5 on Landsat 8

$$
=\text { Red red reflectance or reflected light, Band }
$$$$
4 \text { on Landsat } 8
$$

The vegetation index (NDVI) is then classified into 4 classes, namely $<0.3$ (Non Vegetation), 0.3-0.4 (low), 0.4-0.6 (moderate), $>0.6$ (high). The NDVI value to be obtained is between -1 and 1 . Usually, a value greater than 0.1 indicates an increase in the greenness of the vegetation.

\subsubsection{Derivation of Normalized Difference Built-up Index (NDBI)}

Building density value obtained from processing NDBI value, with the following formula [18].

$$
N D B I=(S W I R-N I R) /(S W I R+N I R)
$$

where

NDBI = Normalized Difference index built-up density of buildings

NIR = Near-infrared reflectance or near-infrared light, Band 5 on Landsat 8

SWIR = Shortwave infrared, Band 6 on Landsat 8

Building density value to be obtained is between -1 to 1 . The density of buildings are classified into 4 classes: <-0.15 (non-built land), -0,15- -0.1 (low), -0.1 0,1 (moderate), $>0.1$ (high). The results of the classification are interpreted in the form of a map.

\subsubsection{Derivation of Land Cover Classification}

Land cover in this research obtained from digitized in Google Earth. Land Cover of Campus IPB Bogor obtained from the processing of digitized Google Earth in 2013, 2015 and 2018 because it is based on significant changes in land cover found in these years to facilitate the visual analysis, especially on analysis visual map comparison. To find out the development of land cover in IPB Campus, the Google Earth application was used by using historical imagery tools. This study used Google Earth image data with historical imagery tools in 2013.2015 and 2018. Digitizing land cover directly on Google Earth based on land cover classification. The nomenclature used was the nomenclature from Badan Standarisasi Nasional in 2010 which was later generalized by land cover in the campus area IPB Bogor. The result is a map of land cover classification into a water body, vegetation, and built-up land, open land and farmland. Each classification will be calculated the area each year and seen changes in the area over the years.

\subsubsection{Field Data Collection}

Air temperature data in this study obtained from direct measurements in the field. Results of field measurements processed based on the type of land cover. Land cover in the form of a water body, vegetation, built-up land, open land, and farmland. Of each land, cover obtained two 
temperature measurement results directly on-site from 9 am - $3 \mathrm{pm}$. These results were then entered into the software. Processing tabular data in tables per 10 minutes from 9 am - 3 pm. From the table that has been made a graph line was made to see the pattern formed and to determine the maximum and minimum temperatures. From each land cover, the maximum, minimum and average values were calculated. Then from the two results of data measurements on the type of land cover that will be recalculated to find the average value of the maximum, minimum and average in the yields.

\subsection{Data Analysis}

The analysis used was the spatial and temporal analysis of land surface temperatures in 2013-2018. The land surface temperature data that has been obtained from the results of data processing will be used as material for spatial analysis to see variations in land surface temperature. The spatial and temporal analysis was used to determine the pattern of land cover changes in 20132018 using visual map comparison analysis by looking at the changes in each land on the map and changes in the area data from each year. Then the data that has been obtained will be connected between the land surface temperature with the density of vegetation and built-up density using statistical analysis.

In addition to qualitative analysis in the form of visual map comparison analysis, quantitative analyses were also carried out in the form of statistical calculations. Statistical analysis was used to analyze how relationships and influences between variables. The statistical analysis used is a correlation and simple linear regression to see the correlation between variables and how the next relationship. After the correlation results were obtained, it will be continued with a simple linear regression analysis to find out the further relationship of the two variables whether one variable (free) has an influence on other variables. The variables used were land surface temperature, NDVI and NDBI. This statistical study, analysis was used to analyze the relationship between land cover seen from the vegetation density and built-up density to the land surface temperature at IPB Campus.

\section{Result and Discussion}

\subsection{Land Cover}

Land Cover of IPB Campus obtained from the processing of digitized Google Earth in 2013, 2015 and 2018 because it is based on significant changes in land cover found in these years so as to facilitate analysis of particular analysis like visual map comparison. Land cover classification produced is a water body, vegetation, built-up land, farmland and open land. The result is the built-up area increasing from year to year, followed by a decline of extensive vegetation. Table 2 shows the area of land cover on IPB Campus.
Table 2. Land Cover Area in IPB Campus

\begin{tabular}{ccccccc}
\hline \multirow{2}{*}{ Land Cover } & \multicolumn{2}{c}{2013} & \multicolumn{2}{c}{2015} & \multicolumn{2}{c}{2018} \\
\cline { 2 - 7 } & Area (ha) & $\%$ & Area (ha) & $\%$ & Area (ha) & $\%$ \\
\hline Water Body & 1,04 & 0,44 & 1,04 & 0,44 & 1,04 & 0,44 \\
\hline Vegetation & 152,44 & 63,59 & 147,37 & 61,47 & 145,46 & 60,68 \\
\hline Built-up Land & 45,70 & 19,06 & 46,14 & 19,25 & 50,48 & 21,06 \\
\hline Farm Land & 37,73 & 15,74 & 39,45 & 16,45 & 38,25 & 15,96 \\
\hline Open Space Land & 2,82 & 1,18 & 5,73 & 2,39 & 4,50 & 1,88 \\
\hline Total & 240 & 100,00 & 240 & 100,00 & 240 & 100,00 \\
\hline
\end{tabular}

Table 2 shows the changes in land cover in 2013, 2015 and 2018. In the three years, there were significant land cover changes from other years. The area of vegetation cover in the form of trees decreases every year from $152.44 \mathrm{Ha}$ in 2013 to $147.37 \mathrm{Ha}$ in 2015 and $145.46 \mathrm{Ha}$ in 2018 which decreased from $63,59 \%$ in 2013 to 60.68 $\%$ in 2018. Changes in built-up land increased from $19.06 \%$ in 2013 to $19.25 \%$ in 2015 and increased significantly again to $21.06 \%$ in 2018 . The addition of built-up land area is due to the development process of campus facilities such as lecture buildings, laboratories, and other supporting buildings, as well as the addition of open land due to the process of adding areas to construct new buildings as initial land. This is due to a large amount of vegetation that is cleared/leveled to be used as land early in the construction phase of new buildings. Figure 2 shows a map of the area of addition to the builtup area in the form of lecture buildings and the addition of open land area as the initial land for the development phase in 2013, 2015 and 2018.



Fig. 2. The image of the process and changes of land cover in IPB Campus

\subsection{Land Surface Temperature}

The results show the land surface temperature changes during 2013-2018 were taken in the range from July to August in the summer. In 2013, the highest temperature was $29.1{ }^{\circ} \mathrm{C}$ with the lowest value of $23.9^{\circ} \mathrm{C}$. Whereas in 2014, the temperature tended to experience a slight decline where the highest temperature was $28.6^{\circ} \mathrm{C}$ and the lowest temperature was $23.4{ }^{\circ} \mathrm{C}$. In 2015 the temperature increased where the highest temperature was $30.8{ }^{\circ} \mathrm{C}$ and the lowest was $25.1{ }^{\circ} \mathrm{C}$. This increase is characterized by the change in land from vegetation to built-up land and open land. Whereas in 2016 and 2017 
there was a slight decline with the highest values of 29.9 ${ }^{\circ} \mathrm{C}$ and $29.5^{\circ} \mathrm{C}$ and the lowest of $24.4{ }^{\circ} \mathrm{C}$. In 2018 there was a very significant increase in which the highest temperature value was $34.8{ }^{\circ} \mathrm{C}$ and the lowest was 27.8 , this was due to the presence of a lot of built-up lands which had increased the land surface temperature in the Dramaga Bogor IPB. In general, seen from the average temperature from 2013-2018, it tends to increase with the initial average value in 2013 which is $25.7^{\circ} \mathrm{C}$ and in 2018 to be $29.96{ }^{\circ} \mathrm{C}$. The increase that occurred in 2013 2017 was not too significant and experienced fluctuations in average values in the range of $25-27^{\circ} \mathrm{C}$ but increased significantly in 2018 with values reaching $29.96{ }^{\circ} \mathrm{C}$

Increasing the value of land surface temperature in the assessment of the results of imagery with thermal bands and associated with changes in land cover in each year due to changes in land cover in each year with significant value in 2015 and 2018 so that the value of land surface temperature also increased significantly in those years. Table 3 and Figure 3 show the value of land surface temperature in 2013-2018.

Table 3. Temporal LST in IPB Campus in 2013-2018

\begin{tabular}{ccccc}
\hline Year & Date & $\operatorname{Max}\left({ }^{\circ} \mathrm{C}\right)$ & Min $\left({ }^{\circ} \mathrm{C}\right)$ & Avg. $\left({ }^{\circ} \mathrm{C}\right)$ \\
\hline 2013 & 08-Jul & 29,1 & 23,9 & 25,7 \\
\hline 2014 & 12-Aug & 28,6 & 23,4 & 25,1 \\
\hline 2015 & 30-Jul & 30,8 & 25,1 & 27,04 \\
\hline 2016 & 01-Aug & 29,9 & 24,4 & 26,3 \\
\hline 2017 & 19-Jul & 29,5 & 24,4 & 26 \\
\hline 2018 & 22-Jul & 34,8 & 27,8 & 29,96 \\
\hline
\end{tabular}

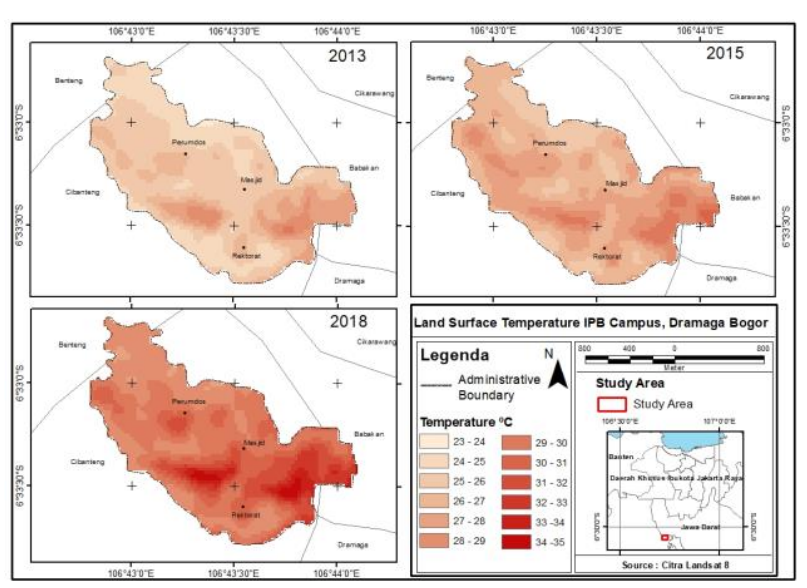

Fig. 3. Land Surface Temperature of IPB Campus.

\subsection{Vegetation Density (NDVI)}

The results show there are four classifications of nonvegetation, low, medium and high. "None Vegetation" classes when compared with land cover in the Dramaga Bogor IPB campus area are found inbuilt and open land areas which increased from 20.52 hectares in 2013 to 22.32 hectares in 2015 and significantly increased in 2018 to become 27.18 Hectares. This indicates that development did occur in those years on the IPB campus and the reduced class of high vegetation density indicates that the development transformed the vegetation land into built-up lands such as building, road network and parking area. The density distribution pattern of high-value vegetation is located in the northern part of the IPB Campus, Dramaga Bogor with the type of land cover vegetation in the form of forest campus. For another class, low vegetation density is located in the center of the IPB campus and groups in the built-up area in the form of building, laboratory, road network, parking area. Table 4 shows the index of vegetation density and its area on the IPB campus, Dramaga Bogor.

Table 4. NDVI Classification Area of IPB Campus

\begin{tabular}{ccccccc}
\hline \multirow{2}{*}{ Classification } & \multicolumn{2}{c}{2013} & \multicolumn{2}{c}{2015} & \multicolumn{2}{c}{2018} \\
\cline { 2 - 7 } & Area (ha) & $\%$ & Area (ha) & $\%$ & Area (ha) & $\%$ \\
\hline Non Vegetation & 20,52 & 8,54 & 22,32 & 9,29 & 27,18 & 11,32 \\
\hline Low & 9,09 & 3,78 & 13,86 & 5,77 & 11,25 & 4,68 \\
\hline Moderate & 12,69 & 5,28 & 19,62 & 8,17 & 32,04 & 13,34 \\
\hline High & 197,91 & 82,39 & 184,41 & 76,77 & 169,74 & 70,66 \\
\hline
\end{tabular}

The addition of extensive non-vegetation classes is due to the development process of campus facilities such as lecture buildings, laboratories, and other supporting buildings. When viewed on the map of the addition of the area when compared with changes in land cover have similarities and linear where in the area of the lecture building there is the addition of built-up land for lecture buildings which in image processing for NDVI there is also the addition of non-vegetation class area in the same area. Development that occurred shows a change in high vegetation density into non-vegetation class. Figure 4 shows changes in vegetation density in IPB.

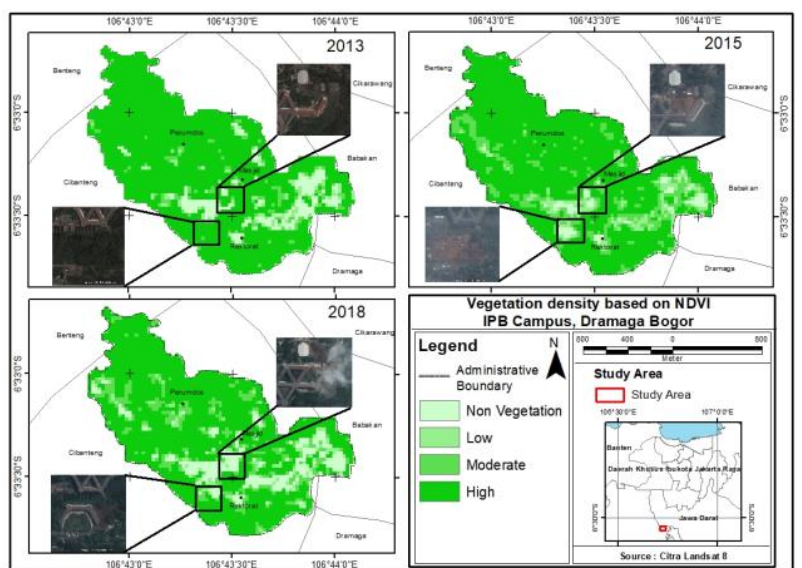

Fig. 4. The image of the vegetation density change in IPB Campus 2013,2015 and 2018

\subsection{Built-Up Density (NDBI)}

The results show there are 4 classifications namely nonbuilt-up, low, moderate and high. From the results of data processing, the area of non-built areas was seen to be decreased, followed by the addition of high-density built-up class areas from $0.99 \mathrm{Ha}$ in 2013 to 2.42 and $3.15 \mathrm{Ha}$ in 2015 and 2018. This indicates development 
occurs in non-built areas and low density. The high distribution pattern of the class of built-up density is located in the area with the type of land cover in the form of built-up land and open land. Low density and non-built density classes are clustered in areas with land cover in the form of vegetation. NDBI class and its area can be seen in Table 5 .

Table 5. NDBI Classification Area of IPB Campus

\begin{tabular}{ccccccc}
\hline \multirow{2}{*}{ Classification } & \multicolumn{2}{c}{2013} & \multicolumn{2}{c}{2015} & \multicolumn{2}{c}{2018} \\
\cline { 2 - 7 } & Area (ha) & $\%$ & Area (ha) & $\%$ & Area (ha) & $\%$ \\
\hline Non- Built-up & 198,00 & 82,43 & 196,83 & 81,94 & 194,31 & 80,89 \\
\hline Low & 14,85 & 6,18 & 14,67 & 6,11 & 15,30 & 6,37 \\
\hline Moderate & 26,37 & 10,98 & 26,28 & 10,94 & 27,45 & 11,43 \\
\hline High & 0,99 & 0,41 & 2,42 & 1,01 & 3,15 & 1,31
\end{tabular}

It can be seen that there is a difference in the class of building density that is very clearly seen, one of which is in the area of the lecture building which has expansion and construction of new buildings. This can be shown by Google Earth satellite imagery where in 2013 it was still in the form of vegetation. In 2015 the initial stage of development was achieved by clearing vegetation or initial equalization as the initial land for building construction to become open land. In 2018 new buildings have been built to influence building density as seen on the map. Figure 5 shows the change in built-up density in IPB.

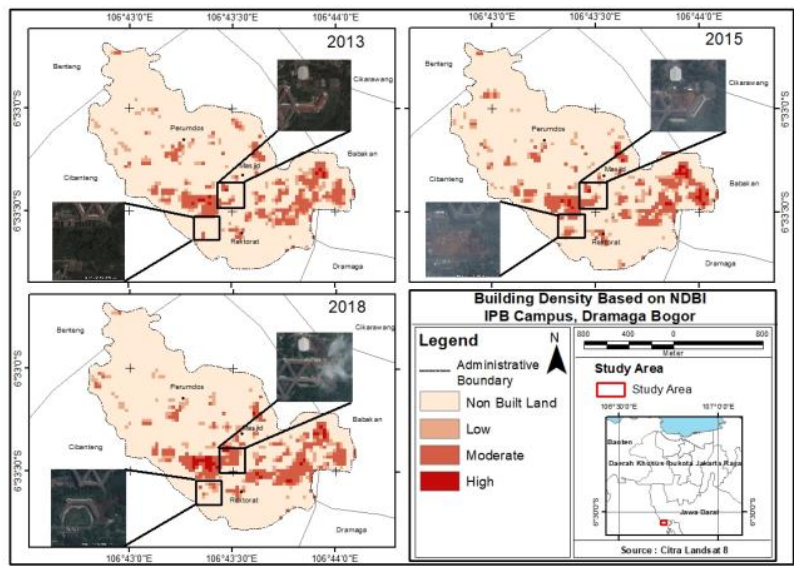

Fig. 5. The image of the built-up density change in IPB Campus 2013,2015 and 2018

\subsection{Relationship Between Land Surface Temperature with Land Cover and Its Changes}

Land cover in the IPB campus area has 5 classifications with different characteristics. The characteristics of each type of land cover can affect the variation in surface temperature on the Dramaga Bogor IPB campus. In its development, there was a change in land cover on IPB campus from 2013-2018 which also affected variations in surface temperature in the campus area. Table 6 shows the land surface temperature in each different land cover.
Table 6. Land Surface Temperature in each Land Cover in IPB

\begin{tabular}{cccccccccc}
\hline \multirow{2}{*}{ Land Cover } & \multicolumn{3}{c}{2013} & \multicolumn{3}{c}{2015} & & & 2018 \\
\cline { 2 - 11 } & Min & Max & Avg & Min & Max & Avg & Min & Max & Avg \\
\hline Vegetation & 23,9 & 28,4 & 25,5 & 25,1 & 30,5 & 26,8 & 27,8 & 34,1 & 29,7 \\
\hline Built-up Land & 24,5 & 29,1 & 26,7 & 25,7 & 30,8 & 28,1 & 28,2 & 34,8 & 31,4 \\
\hline Open Space Land & 25,1 & 26,4 & 25,6 & 26,2 & 28,4 & 27,4 & 28,4 & 32,6 & 30,3 \\
\hline Farm Land & 24,4 & 26,1 & 25,5 & 25,8 & 28,6 & 26,9 & 27,9 & 31,3 & 29,9 \\
\hline Water Body & 24,9 & 25,9 & 25,4 & 26,6 & 28,5 & 27,2 & 29,6 & 31 & 30,1 \\
\hline
\end{tabular}

From Table 6 it can be seen that the highest average temperature in 2013-2018 always lies in the area with land cover in the form of built-up land. The highest average temperature in built-up land continued to increase from 2013-2018 where temperatures reached $31.4^{\circ} \mathrm{C}$ in 2018 . While the lowest average temperatures in 2013-2018 always lie in areas with vegetation land cover. The lowest temperature on average for vegetation land also continued to increase from 2013-2018 where temperatures reached $29.7{ }^{\circ} \mathrm{C}$ in 2018. This overall indicates that land surface temperatures have different values based on each type of land cover and have a trend that shows an increase in heat levels in each land cover from 2013-2018. This can be proven by the increase in temperature in the built area with an average temperature of $26.7^{\circ} \mathrm{C}$ in 2013 to 31.4 in 2018 . Whereas in the vegetation region the temperature increases with an average temperature of $25.5{ }^{\circ} \mathrm{C}$ in 2013 to $29.7{ }^{\circ} \mathrm{C}$ in 2018. The variation in temperature is due to the influence of different types of land cover and increase in temperature each year due to the development process from 2013-2015 resulting in the addition of new buildings that also increase surface temperatures on the Dramaga IPB campus Bogor.

To get a detailed distribution pattern, a transect/transect line will be drawn to see the relationship between land surface temperature and land cover in the Dramaga Bogor IPB campus. Figure 6 shows a land cover map that is traversed by crosssections A1-B1, A2-B2, C1-D1, and C2 - D2.

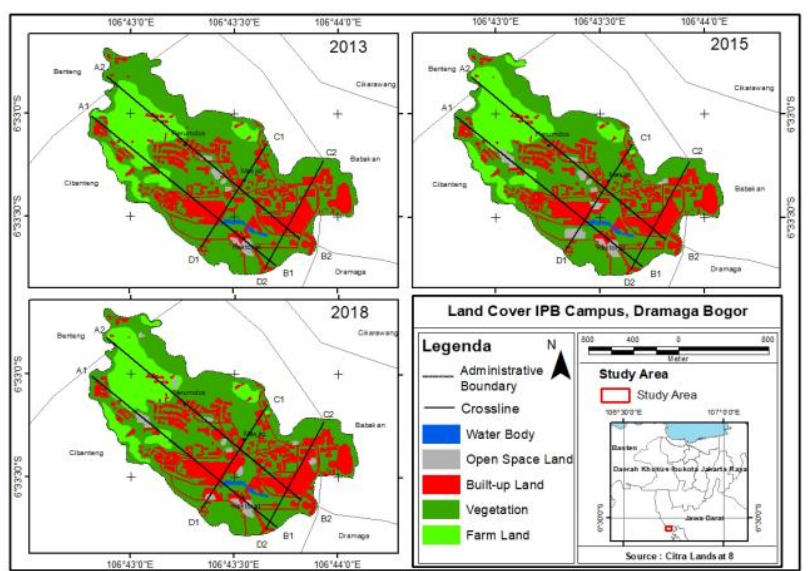

Fig. 6. Cross-section location on land cover of IPB campus

The reason for choosing these 4 cross-sections represents each type of land cover that also changes from 2013-2018. The cross-section describes several types of land cover and also undergoes changes such as the example of vegetation changing into open land and built land. The cross-section also shows variations in the 
temperature values that are crossed by these crossings from year to year so that they indicate a change or a trend of rising surface temperatures in the area crossed by the cross-section. From the results of cross-section extraction, a graph of variation of the surface temperature along the line is produced. In Figure 7 it is a cross-section of points A1-B1, A2-B2, C1-D1, and C2D2 in 2013, 2015 and 2018. In the cross-section, it can be seen that there is a fluctuation in the surface temperature of the land based on the type of land cover. In the three data generated from the 4 cross-sections below, there is a high-temperature grouping in the built area in the form of a lecture building. For low temperature grouping, the area with the type of land cover in the form of vegetation, such as the IPB campus forest.

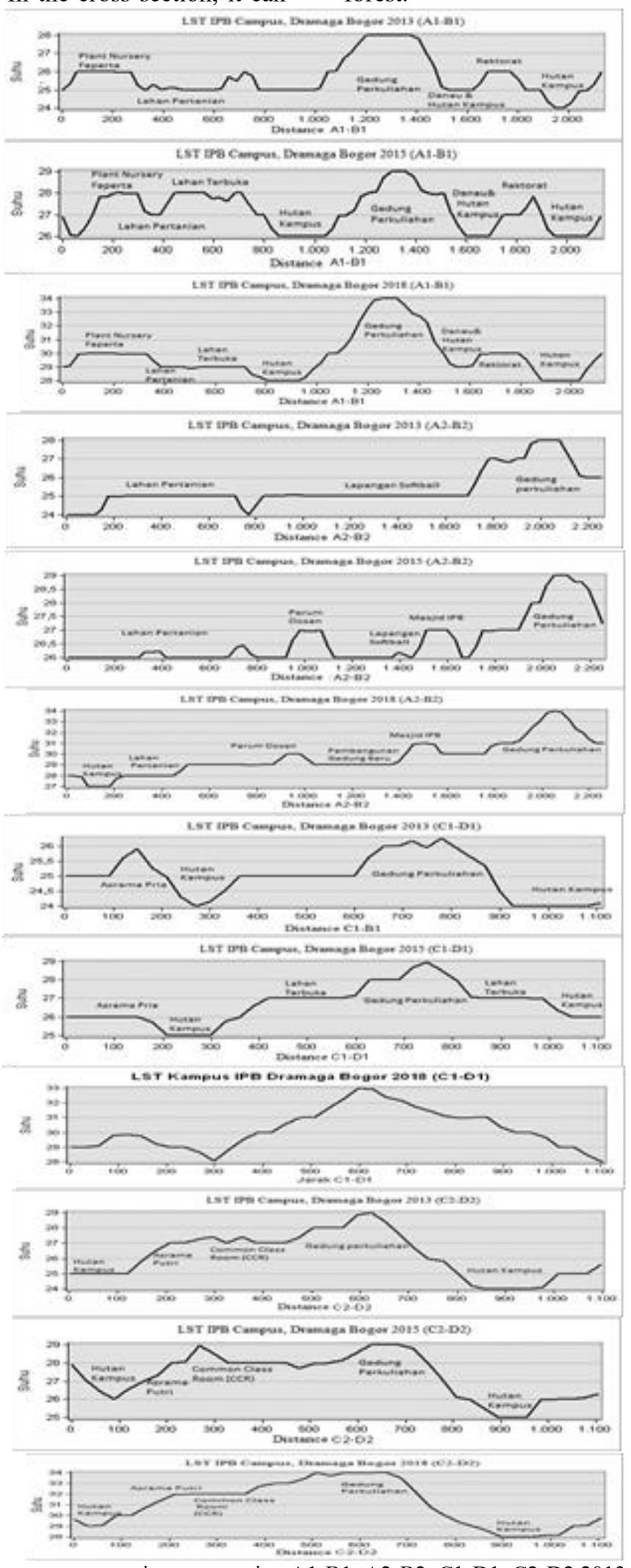

Fig. 7. Graph of value land surface temperature in cross section A1-B1, A2-B2, C1-D1, C2-D2 2013,2015 and 2018 
Basically, the cross-sectional patterns in 2013, 2015 and 2018 are relatively similar, only a few significant changes at certain distances. Temperatures will decrease in areas where vegetation land cover consisting of forests with a range of values between $24-28^{\circ} \mathrm{C}$ and increasing compilation into the built-up area includes campus areas such as lectures with a range of values between 27 $34^{\circ} \mathrm{C}$ in 2013,2014 and 2018 , it can be seen a pattern of variations in surface temperature of land cover on the IPB Dramaga Bogor campus. Based on the cross-section, it can be seen that the land surface temperature is related to differences in land cover and changes in existing land cover. On the land cover that is located on the ground built like a lecture building, has a high temperature and high built-up density. While the land cover in the vegetation consists of forests that have low temperatures which also have high vegetation density.

Because the study found a pattern of temperature variations related to existing land cover where the highest temperature in the built area and the lowest temperature in the vegetated area, then the temperature was taken directly in the field to validate the pattern of temperature variations in the IPB Campus, Dramaga Bogor. The field temperature is taken at 10 sample points, where 10 points are located in 5 different types of land cover. Each sample location is used to identify the air surface temperature associated with the type of land cover as validation. Table 7 shows the temperature in the sample.

Table 7. Air Temperature of Each Land Cover at the IPB Campus

\begin{tabular}{cccc}
\hline \multirow{2}{*}{ Land Cover } & \multicolumn{3}{c}{ 26 March - 6 April 2019 } \\
\cline { 2 - 4 } & Min & Max & Avg \\
\hline Vegetation & 30,6 & 35,1 & 33,2 \\
\hline Built-up Land & 31,3 & 38 & 35,4 \\
\hline Open Space Land & 31 & 36,2 & 33,9 \\
\hline Farm Land & 31,2 & 35,9 & 33,7 \\
\hline Water Body & 30,9 & 35,7 & 33,7 \\
\hline
\end{tabular}

From table 7, air temperature variations are obtained from field measurements as a validation stating that temperatures have different values based on the type of land cover. The lowest temperature lies in land cover in the form of vegetation with a daily average value in the range of $9 \mathrm{am}-3 \mathrm{pm}$ at $33.2^{\circ} \mathrm{C}$ and the highest temperature lies in buildings with daily average values of $9 \mathrm{am}-3 \mathrm{pm}$ at $35,4{ }^{\circ} \mathrm{C}$. Whereas for the daily average value of other types of land cover is located between vegetation land cover and built up land with a value of $33.7^{\circ} \mathrm{C}$ and 33.9 ${ }^{\circ} \mathrm{C}$.

Based on the results of field temperature data retrieval as validation, it was found that the distribution patterns of temperature variations both air temperature and land surface temperature were related to land cover and also the changes that were on the campus of IPB dramaga Bogor. This can be identified on land cover maps and LST by grid analysis and visual map comparison. Figure 8 and Table 8 show a map of land change based on the grid and the value of the changes. Grid and visual map comparison analysis were used to identify which grids had land cover changes in 2013 and 2018 and whether they affected the value of land surface temperature in the grid area. From the results there are areas that experience land changes which are on the grid of $3 \mathrm{C}, 4 \mathrm{C}, 5 \mathrm{C}, 5 \mathrm{~J}, 6 \mathrm{~K}, 8 \mathrm{G}, 9 \mathrm{H}, 11 \mathrm{Q}, 12 \mathrm{~J}, 12 \mathrm{~L}, 12 \mathrm{Q}$, $13 \mathrm{~N}, 13 \mathrm{O}, 14 \mathrm{M}, 14 \mathrm{~N}, 14 \mathrm{O}, 15 \mathrm{P}, 18 \mathrm{~L}, 19 \mathrm{M}, 20 \mathrm{M}, 20 \mathrm{~N}$, 20Q, 21O, 22M and 22O. From changes in land there are areas that have experienced extensive changes such as in the grid 5J, 11Q, 12L, 12Q, 13N, 13Q, 14M, and 14N. Whereas on the other grid land changes only undergo relatively small changes. Figure 8 shows a map of land cover change based on a grid.

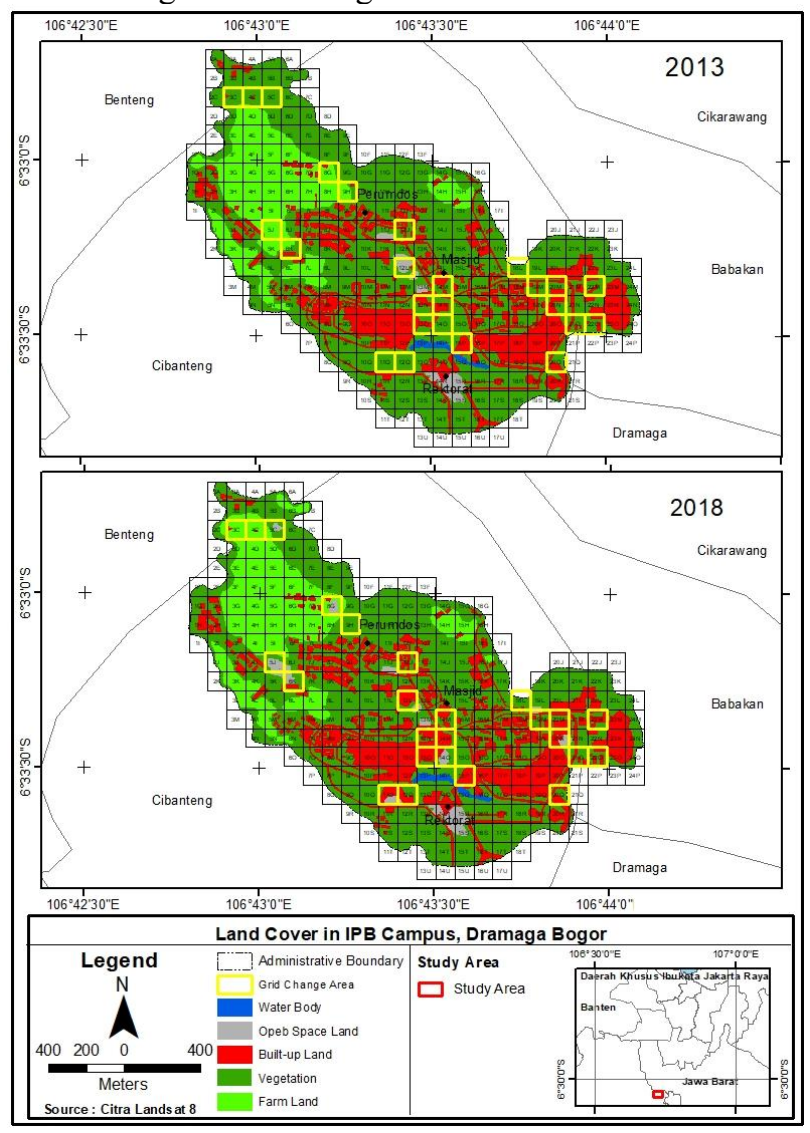

Fig. 8. Map of Land Cover Change

From the results of the analysis, it can be concluded that changes in land cover affect variations in land surface temperature in 2015-2018. Changes in land cover also affect the increase in land surface temperature each year between 2013-2018. When compared to the increase in the average temperature in each type of land cover that was the same in 2013-2018, the value of the increase in temperature was $4.2-4.7{ }^{\circ} \mathrm{C}$. While the increase in the average temperature in areas experiencing changes in land cover in 2013-2018 experienced an increase in temperature of $4.2-7^{\circ} \mathrm{C}$ where the highest increase in temperature occurred in land cover which has changed from vegetation land cover to built land of $7^{\circ} \mathrm{C}$ and the lowest increase occurred in land cover which changed from agricultural land cover to vegetation at 4.2 ${ }^{\circ} \mathrm{C}$. Table 8 shows the results of temperature from 
processing data that have increased based on land cover changes from grid analysis and visual map comparison.

Table 8. Average Temperature Change

\begin{tabular}{|c|c|c|c|c|}
\hline Grid & $\begin{array}{c}2013 \\
\left({ }^{\circ} \mathrm{C}\right)\end{array}$ & $\begin{array}{c}2018 \\
\left({ }^{\circ} \mathrm{C}\right)\end{array}$ & $\begin{array}{c}\text { Enhancement } \\
\left({ }^{\circ} \mathrm{C}\right)\end{array}$ & Information \\
\hline $5 \mathrm{~J}$ & 25,67 & 30,34 & 4,7 & \multirow{3}{*}{$\begin{array}{c}\text { Farm Land }>\text { Open } \\
\text { Space Land }\end{array}$} \\
\hline $6 \mathrm{~K}$ & 25,88 & 30,46 & 4,6 & \\
\hline $8 \mathrm{G}$ & 24,81 & 29,29 & 4,5 & \\
\hline $12 \mathrm{~L}$ & 25,32 & 30,20 & 4,9 & $\begin{array}{c}\text { Open Space Land > } \\
\text { Built-up Land }\end{array}$ \\
\hline $11 \mathrm{Q}$ & 24,90 & 30,54 & 5,6 & \multirow{8}{*}{$\begin{array}{c}\text { Vegetation }>\text { Built-up } \\
\text { Land (Large New } \\
\text { Building) }\end{array}$} \\
\hline $12 \mathrm{Q}$ & 24,66 & 30,32 & 5,7 & \\
\hline $13 \mathrm{~N}$ & 25,90 & 32,90 & 7,0 & \\
\hline 130 & 26,19 & 31,92 & 5,7 & \\
\hline $14 \mathrm{M}$ & 25,75 & 31,00 & 5,2 & \\
\hline $14 \mathrm{~N}$ & 25,79 & 31,15 & 5,4 & \\
\hline $15 \mathrm{P}$ & 26,04 & 31,59 & 5,5 & \\
\hline $19 \mathrm{M}$ & 26,25 & 31,66 & 5,4 & \\
\hline $12 \mathrm{~J}$ & 25,87 & 30,46 & 4,6 & \multirow{7}{*}{$\begin{array}{l}\text { Vegetation }>\text { Built-up } \\
\text { Land (Relatively New } \\
\text { Small Building) }\end{array}$} \\
\hline $18 \mathrm{~L}$ & 25,59 & 30,38 & 4,8 & \\
\hline $20 \mathrm{M}$ & 27,77 & 32,61 & 4,8 & \\
\hline $20 \mathrm{Q}$ & 27,19 & 32,00 & 4,8 & \\
\hline 210 & 27,56 & 32,13 & 4,6 & \\
\hline $22 \mathrm{M}$ & 26,64 & 31,22 & 4,6 & \\
\hline $22 \mathrm{O}$ & 27,47 & 32,41 & 4,9 & \\
\hline $5 \mathrm{C}$ & 24,60 & 28,90 & 4,3 & \multirow{3}{*}{$\begin{array}{c}\text { Vegetation }>\text { Open } \\
\text { Space Land }\end{array}$} \\
\hline 140 & 25,76 & 30,48 & 4,7 & \\
\hline $20 \mathrm{~N}$ & 28,12 & 32,49 & 4,4 & \\
\hline $3 \mathrm{C}$ & 24,56 & 28,75 & 4,2 & Vegetation $>$ Farm \\
\hline $4 \mathrm{C}$ & 24,56 & 28,91 & 4,4 & Land \\
\hline $9 \mathrm{H}$ & 24,72 & 28,88 & 4,2 & $\begin{array}{c}\text { Farm Land }> \\
\text { Vegetation }\end{array}$ \\
\hline
\end{tabular}

\subsection{Relationship and Influence of Vegetation Density and Built-up Density with Land Surface Temperature}

To determine the relationship and influence of vegetation density and building density on the surface temperature of the land in detail, a statistical analysis test will be conducted. After obtaining the results of the correlation it will be followed by a simple linear regression analysis to find out the further relationship between the two variables. The statistical analysis uses NDVI value data, NDBI value and land surface temperature taken at all $30 \times 30 \mathrm{~m}$ pixel points according to the spatial resolution of 2013 \& 2018 image processing to facilitate analysis. From the results of data processing obtained 2659 points to be taken NDVI, NDBI and LST values from each point to be used as data in statistical analysis. In the analysis of NDVI and NDBI values are used as independent variables and the LST value is used as the dependent variable. Following are the results of processing statistical analysis for NDVI with LST and NDBI with LST in 2013 and 2018 use SPSS. The result was shown by Table 9 and Table 10 as correlation and regression NDVI with LST in 2013 and 2018. Then Table 11 and Table 12 show the result correlation and regression between NDBI and LST in 2013 and 2018.

Table 9. NDVI correlation and regression with LST in 2013

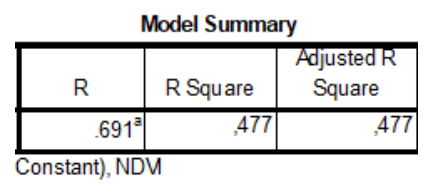

Table 10. NDVI correlation and regression with LST in 2018

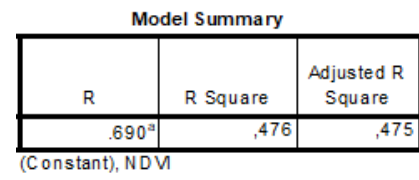

Table 11. NDBI correlation and regression with LST in 2013

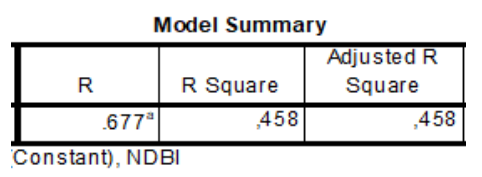

Table 12. NDBI correlation and regression with LST in 2018

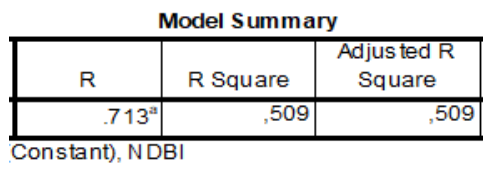

From the results of statistical tests, it can be said that the relationship of NDVI magnitude affects the magnitude of the value of land surface temperature on the IPB campus, Dramaga Bogor. The direction of the graph leading to negative shows an inverse correlation. If the NDVI value rises, then the surface temperature will go down and on the contrary. From the results of the statistical test, it can be said that the relationship of NDBI magnitude affects the magnitude of the value of land surface temperature on IPB campus, Dramaga Bogor. The direction of the graph that leads to a positive direction shows a correlation that is directly proportional. If the NDBI value rises, the surface temperature will rise and on the contrary.

\section{Conclusion}

Based on the results of image analysis, it was found that the land surface temperature at the IPB campus, Dramaga Bogor had a temperature variation with a minimum temperature value of $23.9^{\circ} \mathrm{C}$ and a maximum of $29.1{ }^{\circ} \mathrm{C}$ in 2013 and increased at a minimum temperature of $27.8{ }^{\circ} \mathrm{C}$ and a maximum of $34.8{ }^{\circ} \mathrm{C}$ in 2018. These temperature variations form a spatial pattern where the highest temperature tends to be located in the 
central area of the campus and the lowest temperature tends to be located in the northern region of the campus.

The highest of the land surface temperature lies in the type of land cover in the form of built land with areas with low vegetation cover and tend to be located in the central area of the campus such as lecture buildings and road networks. Whereas for areas with land cover types in the form of vegetation land with high vegetation cover it has the lowest temperature as an example in the IPB campus forest which tends to be located in the northern region of the campus. Changes in land cover have a high influence on variation and increase in land surface temperature in 2013-2018 compared to unchanged land cover. The highest increase in temperature occurs in areas that have changed from vegetation land to built-up land with value $7{ }^{\circ} \mathrm{C}$, while the increase in temperature on similar land cover occurs in built-up land cover with value only $4.7^{\circ} \mathrm{C}$. The results showed that the higher the vegetation density, the lower the land surface temperature, and on the contrary the higher the built-up density, the higher the land surface temperature.

\section{Acknowledgment}

The authors are deeply grateful to Research and Public Service Directorate, Faculty of Mathematics and Natural Sciences, University of Indonesia and also the Department of Geography Faculty of Mathematics and Natural Sciences, the University of Indonesia for support of the research.

\section{References}

1. L. Tursilowati, Pulau Panas Perkotaan Akibat Perubahan Penutupan Lahan di Bandung dan Bogor, 43-64 (2010)

2. R. Nurul Fatimah, UHI Kota Surabaya, 4, 2 (2015)

3. E. Sri Adiningsih, S. Hartati, S.Mujiasih, Kajian Perubahan Spatial Suhu Udara Akibar Perubahan Penutup Lahan, 3, 1 (2001)
4. B. Lakitan, Dasar-dasar Klimatologi, (2002).

5. L. Prihodko, S. Goward, Estimation of Air Surface Temperature From Remotely Surface Observations, 60, 335-346 (1997)

6. A. Benali, A. Carvalho, J.Nunes, Remote Sensing of Environment Estimating Air Surface Temperature In Portugal, 124, 108-121 (2012)

7. P. Vitousek, Beyond Global Warming, 75(5) (1994).

8. Q. Weng, A Remote Sensing-GIS Evaluation of Urban Expansion and Its Impact on Surface Temperature in The Zhujiang, 22, 10 (2001)

9. A. Wibowo, A. Rustanto, Spatial-Temporal Analysis of UHI In Tangerang, 45, 2 (2013)

10. N. Wong, S. Jusuf, A. Aung, H. Kyaw Thu, T. Syatia Negara, Environmental Study Impact of Greenery in Institutional Campus, 42, 2949-2970 (2007)

11. H. Alshuwaikhat, I. Abubakar, An Integrated Approach To Achieving Campus Sustainability, 16, 1777-1785 (2008)

12. A. Wibowo, J. Semedi, K. Salleh, Spatial Temporal Analysis of Urban Hazard on Education Area, 49, 110 (2017)

13. Q. Weng, D. Lu, J. Schubring, Estimation of Land Surface Temperature, 89, 467-483 (2004).

14. Y. Zhang, I. Odeh, C. Han, Bi-Temporal Characterization of Land Surface Temperature, 11, 256-264 (2009).

15. UI Green Matric, UI Green Matric Ranking by Indicators (2018).

16. P. Mirzae, F. Haghighat, GIS Application on urban forest development, 45, 2192-2201 (2010)

17. Y. H. Chen, J. Wang, X. B. Li, A Study on Urban Thermal Field In Summer Based On Satellite Remote Sensing, 4, 55-59 (2002)

18. Y. Zha, J. Gao, Use of Normalized Difference Builtup Index In Automatically Mapping Urban, 24, 583594 (2003) 